\section{“原子力”之“放射線影響” 研究の谷間}

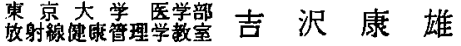

日本の原子力開発が発足して以来，それに関連する 研究はいくつかのグループの下で推進されて来た。て の分け方の是非はここでは触れないか，いわゆる「原 子力」グルーブ，「原子核」グループ、「放射線影響」グル ープなどをその主なるのとして挙げることができる。 強いてあてはめれば私は元来，「放射線影響」グループ に入る人間であるう。接近した領域であるため，課題

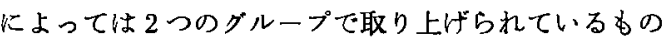
ああるようだがここれは中むをえないし，また考光よ うによっては結構なことですある。素人の私にはよく わからないが、「原子力」と「原子核」の境界をめぐる 論議などは，その1例であ万う。

その点，「放射線影響」グループの課題領域は，原子 力に関する他のグループとの競合（?）といらこともな く進められて来たことは，劣る意味で幸いであった。 名称のうえでは最り暖味な存在でありながら，当初の 予想に反して，市る程度の地位を筑きあげた理由の 1 つもここにあるように思われる。「放射線影響」グルー プと接近しているのは，どちらかといえば「原子力」 グループであ万う。しかし，私の記憶の範囲では，両 グループの境界をめぐって問題が生じ，活発な諭議が 行われたことはかってなかったよ5に思われる。

このような円満な相互関係（？）は考えようによって は妙な現象である。双方の密接な連絡，話合いの結果 円満であるのならば理解できるが，あまり実質的な連 絡がないにもかかわらず問題が生じていないというこ とは，何か重要な問題が抜けていないか？とい5疑 いるもたせる。いいいかえれば，「原子力」と「放射線 影響」との間に谷間があるのでないかという不安であ る。「放射線影響」グループのキャッチフレーズに「原 子力研究と放射線影響研究とは車の両陯である」とい う言葉がある。車の両輪は車の本体で連絡してこそ意 味がある。るし，この間に谷間があるとすれば,「車の 両輪」ではなく、「2つの車輪」に過ぎない。

「原子力」と「放射線影響」とが車の両輪であるた めには，招互いに相手のことを知り合う必要があり。 また，その上で話し合5必要がある。赛質的連絡な く「2つの車陯」に過ぎないのであれば，「何物かを 目標とした便宜的グループ形成」となってしまう括そ れがある。
私のい5谷䦭が致命的な存在として亦るか否かの問 題はしばらくとして，私がつねづ考え，かつ若千の 不安を感じていることの1つを述べてみたい。

それは，「原子力施設で働い従業員」の問題である。 いいかえれば「従業員の管理」の問題であるが，後者の 表現はとかく誤解されやすいのでここでは用いない。

現在までの「故射線影響」グループの研究課題の主 流は，「放射線の生物学的作用機棈」，「放射性物質に 上る環境污染」，それに「原子爆弾に上る障害の没学的 観察」などである。これは，日本が置かれている社会 的環境を考えれば納得のできる傾向ということもでき る。生物学的作用機構の問題は別として, 要するに興 味の焦点は原子力施設外の問題にある。といらこと は，施設内の問題については市まり研究がないという ことでもある。「放射線影響」の対象となる施設内の 問題とは？それは，従業員の安全に関連するものて ある。

原爆被災国といら社会的環境下に扰いて原子力開発 のスタートする立場に置かれたため，公衆問題の解決 が至上課題としてより重視されたことは当然のことて ある。この問題は，いずれにしてもスッキリした型で の解決は望めない。しかし，ある意味で，議論も出つ くし，残った「考え方」の問題を別とすれば，ひと落 着きした今日となってみると，従業員の問題はこのま までよいのか？といら疑問がわいて来る。少なくと も，公采に対する問題はどつきつめた検討をしていな いことは事実である。一部には「従業員(職業人)の問 題は簡単た……といら人るいる。しかし、これは認 識不足である。ある意味で社会的ムートに支配される 公䅇の問題と異なり，職業人の問題は徹頭徹尾，理詰 めである必要がある。産業界の一部には，この問題も ムードで解決できると思い，また，労使の接触点でム 一ドで問題を解決しているところもある。しかし，長 い眼で見た場合，そのような解決は早晚なんらかの型 で破綻を来たすのではないだろらか。

現場の問題は根が深く，かつ広い。それに役立つ科 学的研究を、現在の「放射線影響」グループにゆ及依 在することは無理であるう。産業界に基盤の一部をす つ「原子力」グループから問題の提起があってしかる ベきでる。

この種の問題を取り上げる場として，国内の学会あ るいはそれに類似した主な組織を眺めて見上う。「放 射線影響」グループによる日本放射線影響学会,「原 子力」グループ関保の日本原子力学会は，前に述べた 通り，現状では期待できる雾囲気が少ない。現場の問 
題をかなり血の通った型で取り上げている日本産業医 学会は放射線に関してはまだ関心が5すい。日本医学 放射線学会は，往年はこの問題についてもかなり活発 であったが，近年はこの種の演題は減少した。いずれ にしても，原子力産業、科学に直結した課題を取り上 げる場としては無理なのかも知れない。発足間るない 日本保健物理協議会が今後期待できるが，規模の点で 現状では若干の不安がある。近年, 保健物理に関する 国際的組織が発足する見込みがあるため，本邦でも独 立の協議体を作ったのかす知れないが，日本原子力学 会と別に出来たといらことは, 日本原子力学会として は「この種の問題は本流でない」と割り切ったのであ らうか。この他にも学会的組織でない，同好の果り程 度の組織もあるが，「原子力」の広い視野に立った活 動とい5点に関する限り，少なくとも現状で大大きな 期待をかけることは無理であうう。いずれの組織がそ の問題を取り上げ、また，どの学会が担当すべきであ るかを問題とする必要はないであろう。しかし，どこ
かが真剣に取り上げなければならないことは事実であ る。

原子力安全性, 放射線安全の問題は根が㕕く，かつ 深い。広い総合的視野が要求される。その一部である 従業員の安全の問題は，根の広さにおいては広義の原 子力安全の問題ほどではないが, その樑さにおいては 一般の予想以上のものがある。現場に立脚し，かつ， 広い自然科学的, 社会科学的視野に立っ太検討と考察 が必要である。

この問題を解決するには，経済的背景と同時に， 否，それ以上に「人間(人材)」と，それを有成する社 会的環境が必要である。日本の原子力には「政策あっ て、計画なし」という批判があると聞いている。その 是非は私には判断しかねるが，ただここに私が提示 したような問題わ包含されている本当の意味の総合長 期計画の出現が望委れる。

（1964年 11月13日 受理）

\section{原子力と非破壊検査}

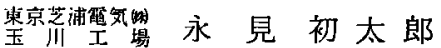

原子力の利用は年々盛んになってきており，原子师 の建設もすでに国内において10数個所に及んでいる が，今後，発電用原子师，船用の動力炉などますます 発展することが考えられる。

原子炉の建設には長い年月，多額の費用打よび多量 の材料を要するが，るしある部分の事故により炉全体 がその機能を停止すると，これを修理し，元の状態に 戻すまで，長期間，师の使用が不能となり，多人の損 害を招くことになる。さらに最悪の場合は, 修理不能 ということも考えられる。

以上のような点から，組立て前あるいは組立て途中 に怙ける綿密な試験検查が要求される。

原子炉を構成する各部分は，その使用に際しての信 頼度は従来の構造物の部品に比較して極めて高度の のが要求されている。このため, 部品, 材料は各種の 検査法によって慎重に調べられているが，その中です 非破坡検査法は重要な検査法の1つである。

非破壊検查は，検查された部品が良品である場合は すぐつぎの組立て工程に送り込めること，すなわち実 際の組立て部品が検查できる点が大きな特長である。
非破壊検查の方法には大別して4つの方法がある。

（1）放射線による透過検查 いろいろなエネルギー のX線や放射性同位元素からの $\gamma$ 線を用いて，久陷の 透過度の差を利用する方法である。

（2）超音波による検查 被検查物に入射した超音波 パルスの反射ェコーの大きさ，時間より欠陥を検出す る方法である。

（3）浸透威による検查 浸透性の上い染色液あるい は螢光液を被検查物に一様に塗布すると割れ久陷江浸 透する。つぎに表面の液をおとし，現像郕を治布する と欠陥中の浸透液が表面に吸い出され，欠䧩が检出て きる。

（4）磁粉による検查 磁性体の被恰查物に電流を流 し, 欠陌があると磁束が乱れて被検査物の表面に出て くる。この部分に磁粉をかけるとこの乱れの部分に集 り，久陥部が直接肉眼で観祭できる。

原子炉に，非破壊検查が応用できるものには，燃料 要素, 燃料要素の被覆, 冷却材などの通るパイブ,チュ ーブ, 熱交換器および圧力容器などがある。

燃料要素およびその被覆の組立て後の曲がり,変形 などは部分的過熱の原因になるが，このよ5な形状検 査には放射線透過検査が適当である。特に照射済み燃 料の再処理の場合, 燃料要素中の燃料の分布, 被覆の最 